Emanuel Feuermann 



\title{
Emanuel Feuermann
}

\author{
Annette Morreau
}

Yale University Press

New Haven and London 


\section{Copyright (C) 2002 by Annette Morreau}

All rights reserved. This book may not be reproduced in whole or in part, in any form (beyond that copying permitted by Sections 107 and 108 of the U.S. Copyright Law and except by reviewers for the public press) without written permission from the publishers.

For information about this and other Yale University Press publications, please contact:

U.S. Office: sales.press@yale.edu www.yalebooks.com

Europe Office: sales@yaleup.co.uk www.yalebooks.co.uk

Set in Minion by Northern Phototypesetting Co. Ltd, Bolton, Lancs

Printed in Great Britain by Biddles Ltd, Guildford and King's Lynn

Library of Congress Cataloging-in-Publication Data

Morreau, Annette.

Emanuel Feuermann/ Annette Morreau.

p. $\mathrm{cm}$.

Includes bibliographical references (p. ) and index.

Discography: p.

ISBN 978-0-300-09684-2 (cloth)

1. Feuermann, Emanuel, 1902-1942. 2. Violoncellists-Biography.

I. Title.

ML418.F49 M66 2002

$787.4^{\prime} 092-\mathrm{dc} 21$

2002002004

A catalogue record for this book is available from the British Library

$\begin{array}{llllllllll}10 & 9 & 8 & 7 & 6 & 5 & 4 & 3 & 2 & 1\end{array}$ 
To the memory of my mother

Beryl Scawen Blunt (1911-1987) 
Even if music and some of its great performers are still a mystery to me, the possibilities and probabilities in doing the most impossible and most improbable things on a cello or any other instrument never will surprise me. ${ }^{\star}$

Emanuel Feuermann 